\title{
Lumen
}

Selected Proceedings from the Canadian Society for Eighteenth-Century Studies

\section{2: Myths and Realities of the Nation-in-Arms}

\section{Ian Germani}

Volume 19, 2000

Material Productions \& Cultural Construction

Culture matérielle \& Constructions discursives

URI : https://id.erudit.org/iderudit/1012322ar

DOI : https://doi.org/10.7202/1012322ar

Aller au sommaire du numéro

Éditeur(s)

Canadian Society for Eighteenth-Century Studies / Société canadienne d'étude du dix-huitième siècle

ISSN

1209-3696 (imprimé)

1927-8284 (numérique)

Découvrir la revue

Citer cet article

Germani, I. (2000). 1792: Myths and Realities of the Nation-in-Arms. Lumen, 19, 153-170. https://doi.org/10.7202/1012322ar

Copyright (c) Canadian Society for Eighteenth-Century Studies / Sociéte canadienne d'étude du dix-huitième siècle, 2000
Ce document est protégé par la loi sur le droit d'auteur. L'utilisation des services d'Érudit (y compris la reproduction) est assujettie à sa politique d'utilisation que vous pouvez consulter en ligne.

https://apropos.erudit.org/fr/usagers/politique-dutilisation/ 


\section{1792: Myths and Realities of the Nation-in-Arms}

It is a commonplace that the French Revolution gave rise to the idea of the 'nation-in-arms,' inaugurating a revolution in warfare every bit as momentous as that which had occurred in the political and social spheres. ${ }^{1}$ The decree of the levée en masse of 23 August, 1793, with its famous preamble calling for every man, woman and child to serve the war effort, encapsulated the nature of this military revolution, defining a program which would ultimately lead, once technology and organization had caught up with ideology, to the phenomenon of total war. Yet the previous year, 1792, had already witnessed the first triumphs for the nation-in-arms, at Valmy, on 20 September, and at Jemappes, on 6 November. Valmy, from the time Goethe uttered his famous words, 'On this day and in this place begins a new epoch in the history of the world,' became emblematic of the invincibility of the nation-in-arms. In the Nineteenth Century, Michelet would celebrate the battle as a popular, rather than just a military triumph. ${ }^{2}$ Louis-Philippe, during the July Monarchy, also sought to exalt the memory of 1792, asserting his republican credentials by underlining his presence on the battlefields of Valmy and Jemappes. The paintings he commissioned for the Salle de 1792 in the Palais de Versailles presented a highly selective interpretation of history, one which, in the words of Michael Marrinan, 'carries us through the last half of that fateful year on a tidal wave of national pride: from the July/September volunteers to Valmy in late September and on to Jemappes in November, the whole orchestrated by France's victorious generals. ${ }^{3}$ Popular prints from the July Monarchy fulfilled the same function. The caption of one celebrated Louis-Philippe's role in defending the famous mill at Valmy: "This heroic resistance covered him with honour and decided the success of that memorable day' (Illustration \#1). This heroic interpretation has inspired twentieth-century echoes, also with political overtones. In 1915, Lalauze sought to sustain the 'union sacrée' binding the socialist heirs of France's revolutionary tradition to the patriotic effort of the First World War by painting the heroes of Valmy saluting the poilus of the trenches. ${ }^{4}$ Later, Jean Renoir's film, $\mathrm{La}$ Marseillaise, would exalt the same heroic myth, celebrating the trium- 
phant passage of a battalion of Marseilles fédérés along the march to Paris, where they storm the Tuileries, and finally to the battlefield at Valmy.

This 'heroic myth' of 1792 has not gone unchallenged. Even as the events of that year unfolded, the right-wing press mocked the ill-discipline and insubordination of the revolutionary armies, contrasting them with the well-ordered might of Prussia and Austria. It gloated at the defeats suffered by the French, and minimized their victories. ${ }^{5}$ Conservative nineteenth-century historians opposed Michelet's history with one that reduced Valmy to an anti-climactic canonnade in which the victors, if there truly were any, were the soldiers of the line army inherited from the old regime rather than the revolution-inspired volunteers of the National Guard - hardly a triumph for the nation-inarms. $^{6}$

Both myths of 1792, the heroic and the anti-heroic, are grounded in reality. The patriotic enthusiasm was real. When, on 12 July, it was proclaimed that 'la patrie est en danger,' Paris was set a target of two volunteer battalions and raised thirty-one. The nation as a whole, asked for 42 battalions, provided 275 . $^{7}$ The patriotic spirit of these volunteers is attested to by their letters. A certain Huret, for example, writing after the battle of Jemappes, recounted the effect General Beurnonville's exhortations had upon his men.

Every soldier felt tears of joy flow down his cheeks, an heroic courage take over him, and fell on his enemy to the sound of fire and the rattle of weapons, and withdrew from the combat only after being covered in the enemy's blood. ${ }^{8}$

On the other hand, many of the volunteers of 1792 took the first opportunity to leave the colours and return home. Officers and, at times, entire units deserted to the enemy. Generals struggled to retain and control their men, a task rendered all the more difficult by the generals' own uncertain loyalties, something which radical journalists like Marat, Prudhomme and Hébert were always ready to point out. The massacre of General Dillon following the failure of the initial offensive in the north, the defection of Lafayette, and the surrender of Longwy and Verdun all provided evidence of the gulf between rhetoric and reality. Isnard, evoking the image of ten million Frenchmen, 'burning with the fire of liberty,' rising up against the despots of Europe, had proclaimed that 'a people in a state of revolution is invincible, ${ }^{, 9}$ but the armies of 1792 were clearly far from invincible.

Patriotic propagandists, journalists in particular, were thus presented with a conundrum: how to sustain the myth of the nation-in-arms in the face of such stark disappointments. If they turned a blind eye to those disappointments and exaggerated the Revolution's triumphs, their 
credibility was likely to be called into question by right-wing journalists anxious to ensure that myth did not become reality; or by radical writers fearful of the dangers to the Revolution both of a complacent public and of victorious generals. The response of the mainstream, patriotic press to this dilemma was to recognize both victory and defeat, success and disappointment, but to draw inspirational messages from both, to insist when possible upon the accomplishments of the nation-in-arms and, when this was not possible, upon its potential. In this way, while purporting to provide an unembellished description of events, the revolutionary press sought to play its part in realizing the myth of the nation-in-arms.

The early reverses threatened to make that myth still-born. As news filtered back to the capital of Biron's retreat from Mons, and of the rout of General Dillon's army before Tournai, there was plenty of evidence for right-wing journalists like Montjoye to exploit, sustaining their view that the revolutionary principles of liberty and equality were inimical to military order and discipline. Montjoye described in graphic detail how Dillon, 'the most honest man, and one of the bravest in France,' had become the victim of his troops' indiscipline.

M. Théobald Dillon returned at four in the afternoon, in a carriage, because he already had a broken leg, and could no longer walk. His carriage had scarcely entered the first street when it was set upon; four troopers made feeble efforts to fend off the attackers; the first blow he received was from a bayonet, and in the same minute a horseman fired a gun at him; he fell in his carriage; they immediately dragged him out, they hung him, by the feet, on the fatal lamp-post, and they riddled him with shots. From there, they dragged him to the square, they lit a bonfire, and sang and danced around the atrocious sacrifice. The feet and hands of the victim sacrificed by injustice and indiscipline, burning more slowly than the rest of his body, were sent to the citadel, as if to make the entire garrison accomplices to the execrable crime. ${ }^{10}$

Two days later, Montjoye reinforced his message, stating that it was 'uniquely an exact discipline and the most complete subordination that make good soldiers and good armies, ${ }^{11}$ and emphasizing that these military virtues had seeped away from the army through the soldiers' attendance at the meetings of popular societies.

Radical journalists responded to these events very differently. To Marat, the murder of Dillon was one of the 'Great examples of popular justice that can save the fatherland, ${ }^{12}$ and Prudhomme insisted that the people and garrison of Lille 'only intended to expiate a public crime and to sacrifice a holocaust to freedom. ${ }^{13}$ The more moderate, patriotic press echoed the radicals' claim that the army had been betrayed, but disputed 
the charges against Dillon and Biron. The Chronique de Paris was willing to admit that Dillon had 'demonstrated incapacity' but noted that 'incapacity is not treason.' ${ }^{14}$ The Annales patriotiques et littéraires de la France pointed an accusing finger at Rochambeau, as well as at the Tuileries and the 'comite Autrichien. ${ }^{15}$ It denounced both the 'scoundrels ... in the pay of the Austrians of Brussels and Paris' who had encouraged the mutinous behaviour of the army, and the traitors of the court who had revealed the army's plans to the enemy. ${ }^{16}$

Above all, though, the patriotic press sought to divert attention from the sad spectacle in the streets of Lille. While denouncing the 'traitors within our armies' who made false cries of treason, the Chronique insisted upon the enthusiasm and discipline that prevailed within the army. ${ }^{17} \mathrm{It}$ described the 'fine retreat' of Biron's army, noting that while Biron 'could not entirely restore order' the spirit of his army was still sound, with both volunteers and regular troops giving a good account of themselves.

The second battalion of volunteers from Paris and the Esterhazy hussars were particularly damaging to the uhlans. These two units, by their ardour, steadfastness, courage, and especially their discipline, gave our army a great example. ${ }^{18}$

The unity and resolve of army and citizens were thereby confirmed.

It was by means of such heroic anecdotes, therefore, that the patriotic press sought to salvage the myth of the nation-in-arms from the opprobrium of defeat and mutiny. In the aftermath of the Dillon massacre, three anecdotes were widely reported in the press. First, there was that of the Grenadier Pie who, wounded in the course of the army's retreat, cried to his officer, 'Finish me off, so that I am not witness to this day's shame; my officer, you see, I die beside by musket, with the sorrow to be unable any longer to carry it. ${ }^{19}$ The letter reporting this incident was read to the National Assembly, which subsequently approved the presentation of a sword to Pie, dedicated to this 'Marius expiring on the ruins of Carthage' by regular and volunteer troops from Paris. ${ }^{20}$ The Gazette universelle reported the 'edifying ceremony' at which the grenadier received his sword, himself articulating the moral of his story: 'My friends, we will be invincible by obeying the orders of our officers, and by the exactitude and the severity of our discipline. ${ }^{21}$

The second anecdote recounted the story of Denis Rousselot, sergeant of a volunteer regiment on the northern frontier. Ambushed by the enemy, Rousselot declared to his men, 'If I fall back, kill me, just as if one of you falls back, I will kill him.' He then led his men back to Condé, firing forty cartridges on the way. Promoted to commissioned rank for his leadership, Rousselot , like Pie, defined the significance of his story: 'What pleases me, is that the eight men in my detachment were all 
recruits and had never been under fire; they fought well...., ${ }^{22}$ In other words, volunteers were indeed dependable troops.

The third anecdote, also from Condé, concerned a young recruit from the same regiment as Rousselot. 'The brave Thénard' was in a company of fifteen men ambushed by sixty Austrian hussars. Of the fifteen, three were killed, four captured and five escaped. Called upon to give himself up, Thénard refused. 'Live free or die!' he cried, blowing out the brains of the nearest Austrian, before succumbing to the enemy, crying to the end, 'Live free or die! ${ }^{\prime 23}$ Within a month, the story of Thenard was being staged for audiences in Paris by the Théâtre de Molière. ${ }^{24}$ The Chronique de Paris questioned the authenticity of the anecdote, and challenged Gorsas, who had first cited it, to produce his evidence. This Gorsas did, inviting his readers, with a certain amount of pique, to visit his office to view the letter from an officer of Thénard's regiment which recounted the incident. ${ }^{25}$

Within a matter of days, then, the revolutionary press devised a formula for sustaining the idea of the nation-in-arms, even in the face of defeat and disappointment. This formula, insisting upon the courage and generosity of French troops, explained their defeats by cowardly and rapacious enemies in terms of treason and inferior numbers. The desertion of officers and men was dismissed as a healthy purge of the national body, and military set-backs compensated for by narrating spectacular acts of individual or collective heroism. Thus, even defeat was held to contain the seeds of victory. 'The reverses that we have just endured are salutary lessons that will produce many, many victories,' wrote the Chronique de Paris on 4 May; 'the indelible certainty of war,' echoed the Annales Patriotiques et Litteraires, 'is a great victory for us, and for all the peoples of Europe, rather than a defeat. ${ }^{.26}$

As the campaign progressed, the pantheon of military heroes expanded. In June, the Theatre de Molière celebrated the 'Hussars of Berchigny,' a regiment of cavalry that had resisted the efforts of its officers to persuade the entire unit to desert. ${ }^{27}$ The Annales Patriotiques, in reporting this incident, had lauded the courage of a non-commissioned officer who had ridden after the deserters, cut one down with his sabre, and returned bearing a recaptured standard: 'this story shows what a brave patriot can do against a hundred or a hundred and fifty traitors who are and who always will be cowards. ${ }^{28}$ The anecdote provided a positive counterpoint to the depressingly familiar reports of military defections. The same issue of the Annales Patriotiques noted the defection of the Royal German cavalry, stating that the horses would be missed, if not the men.

Subsequently, in July, it was the Fernig sisters, the 'Amazons of Dumouriez,' who achieved notoriety. Serving in a volunteer unit raised 
by their father, Théophile and Félicité Fernig attracted the attention of Dumouriez. Their exploits were first publicized in the Argus de l'armée et $d u$ département $d u$ nord, ${ }^{29}$ and then by the Parisian press. The Courrier des départemens reported on 17 July that:

the two Fernig girls, intrepid volunteers, remained constantly in action, and they proved themselves truly to have exceeded their sex. M. Dumouriez could not refrain from recognizing the courage and heroism of these two young patriots, and expressed his admiration to them. ${ }^{30}$

Subsequent issues of the Courrier paid tribute to 'the patriotism and courage' of the Fernigs, and one recounted 'an interesting episode' from the camp de Maulde, when Dumouriez and Félicité Fernig acted as godparents for the daughter of a corporal from Normandy. The representatives on mission to the army of the North played their part in publicizing the exploits of the Fernig sisters, extolling both their 'warlike qualities' and 'the lovely virtues of their sex, sweetness and modesty. ${ }^{, 31}$ Later, in October, a subsequent group of representatives associated the Fernigs with the memory of Joan of Arc:

Under the reign of Charles VIII, a valorous girl armed herself to put a king back on the throne, and under the reign of liberty we have two heroines to fight against the despots. ${ }^{32}$

That their reputation extended far afield is evidenced by the action of a hundred women of Strasbourg, who petitioned the department to allow them to bear pikes and who aspired to emulate 'the generous devotion' of the Fernig sisters. ${ }^{33}$

The tributes to female heroes reinforced the message that the defence of liberty demanded effort and sacrifice even from those members of society traditionally regarded as non-combatants. As the surrender of Longwy and Verdun in late August and early September heightened the sense of crisis, the call to arms became generalized. Prudhomme responded to the fall of Longwy by calling for 'a great popular convul$\operatorname{sion}^{\prime 34}$ to save the fatherland. Gorsas paradoxically referred to the treason of Longwy as a 'victory: it will lift the bloated optimists from their torpor, it will terrify the counter-revolutionaries who will pay with their heads for our slightest set-backs; it will bring forth armies from the land. ${ }^{35}$ Prudhomme's 'popular convulsion' was forthcoming, and in the ensuing issue of his journal he found himself justifying the September massacres and the mutilation of the Princesse de Lamballe. ${ }^{36}$ Other writers turned aside from the carnage in the prisons of Paris, however, to emphasize the more positive aspects of popular mobilization. Carra, 
somewhat remarkably, given the terror of the previous days, wrote under the heading 'Paris' on 7 September:

Enthusiasm and activity are constantly growing: the only sight is of national volunteers gaily leaving for the defence of the fatherland; women work to make knapsacks for them. By a proclamation of the commune, these good citizenesses will unite to sew tents for the Paris encampment; the remaining men will go to work on this camp: everyone participates in these civic corvées; women, children, old men, no-one slacks. ${ }^{37}$

Later, as the resistance of Lille and Thionville to enemy attack provided propagandists with a counterpoint to Longwy and Verdun, writers continued to insist upon the resistance of every element of the population to enemy invasion. Reports from Lille cited the heroic examples of a citizen who continued to man the defences despite the destruction of his home by fire, of a citizeness who served the artillery on the ramparts, and of children who chased after explosive shells to extinguish their matches (Illustration \#2). ${ }^{38}$ Reports from Thionville described women and children dancing among the guns as they fired on the enemy. Symbolic gestures of defiance were emphasized - the construction of a wooden horse with a feed-bag of hay and a sign: 'when the horse has eaten the hay, Thionville will surrender. ${ }^{, 39}$

Military heroes were not forgotten. On 20 September, the National Convention applauded the action of the 'three hussars of Thionville' who had fought their way through enemy lines to deliver dispatches to Metz (Illustration \#3). ${ }^{40}$ The surrender of Verdun itself provided one of the most celebrated heroes of the Revolution. Beaurepaire was the commander of the garrison. His death, as reported in the press, had all the key ingredients of revolutionary heroism: voluntary self-sacrifice, uncompromising resistance to both internal and external enemies, and memorable last words. 'I die free!' he purportedly declared, blowing his own brains out in the presence of the council whose decision to surrender he refused to accept (Illustration \#4). ${ }^{41}$ In calling for his admission to the Pantheon, Delaunay declared that Beaurepaire had judged 'that his death would be more useful to the fatherland than his life.' He evoked the vision of the martyr of liberty's body passing through the battalions of troops extending from the Pantheon to SainteMenehould, inspiring the courage of troops leaving for the front. ${ }^{42}$ It is this vision perhaps, which inspired one of the Tableaux historiques de la révolution française depicting Beaurepaire's body being carried away from the city of Verdun (Illustration \#5). Delaunay's account of Beaurepaire's death, however, was a complete fabrication. The officer did not end his life in the presence of the defence council, but alone, in his room. 
Doubt persists as to whether he shot himself or whether he was assassinated. ${ }^{43}$

Officers, representatives on mission, deputies, journalists, playwrights and artists all collaborated in fabricating the heroes of 1792. As defeat turned to victory, beginning with Valmy, those heroes multiplied. Valmy and Jemappes both produced their share. Following Jemappes, for example, General Beurnonville recognized the heroism of Bertèche, a trooper who killed seven enemy dragoons and received forty-one sabre-cuts and a bullet-wound in return. ${ }^{44}$ Dumouriez himself praised the role of Philippe Egalité, ${ }^{45}$ and Ronsin, a commissar attached to the army, paid tribute to Baptiste, Dumouriez's valet, who had helped to rally the troops at the crucial moment, and who was rewarded by the Convention with a volunteer's uniform. ${ }^{46}$ A contemporary print highlighted the roles of Orléans, Baptiste and Dumouriez as they led the French troops against the third line of enemy breastworks (Illustration \#6). Ronsin's report, which exalted the heroism of the entire army, including that of dying men 'who struggled to gather what little strength remained to them to ask us if we were victorious,' represented the battle as clear evidence of the invincibility of a free people.

The reliability of these reports, as we have seen, was sometimes called into question even by patriotic writers. Marat was highly critical of Dumouriez's account of Jemappes. ${ }^{47}$ Of Beurnonville's reports of his operations along the Rhine, Arthur Chuquet has written, 'nowhere in the military annals of Europe is anything more incredible to be found. ${ }^{48}$ Gorsas complained that Beurnonville's letters to the Convention said nothing about the erosion of his force as soldiers fell down snow-covered gorges, or deserted to the enemy, or filled the hospitals. ${ }^{49}$ Gorsas recognized, perhaps, that implausibly positive reports simply encouraged the mockery of right-wing journalists intent upon deriding the revolutionary war effort. The Feuille du Matin did not fail to mock Beurnonville's outrageous claim that his army had killed a thousand Austrians for the loss of one soldier's little finger:

The new successes of the brave Ajax Bournonville [sic] fill the hearts of all good patriots with hilarity; but they cost us dearly: a terrible bomb weighing five hundred pounds fell on the little finger of one of our brave volunteers, and entirely broke it. ${ }^{50}$

Such satire was an effective way to undermine the propaganda of revolutionary publicists. Custine was another general whose tall tales had ultimately to be disavowed. His claim that Frankfurt was lost in December through the action of ten thousand traitors armed with dag- 
gers had ultimately to be disavowed, although it did give rise to some lurid illustrations (Illustration \#7). ${ }^{51}$

Voices that dissented from the dominant discourse 'of valour and victory ${ }^{\prime 52}$ were still to be heard as the campaign of 1792 drew to a close, although those voices were somewhat muted by the censorship imposed after 10 August. Perhaps it was the persistence of those voices that explains why the Annales Patriotiques judged public opinion on the war to be still unformed in October (ibid.). But perhaps it was that discourse itself which failed to convince. The Annales published a suggestive commentary from the Journal de Paris which complained that 'it is always in the joy and glory of success that the commissars and generals write.' What was lacking was precise calculation of the relative strengths of French and enemy forces: 'It is always science that is missing from the public's understanding' (ibid.). The myth-makers of 1792 provided a wealth of inspirational anecdote and thereby helped to create the nationin-arms. Their success in convincing the public, however, was as incomplete as that of the phenomenon - the nation-in-arms - they purported to describe.

\section{IAN GERMANI}

University of Regina

\section{Notes}

1 Hew Strachan, 'The Nation in Arms,' in The Permanent Revolution: The French Revolution and its Legacy, 1789-1989, ed. Geoffrey Best (London: Fontana, 1988), pp. 49-73.

2 Jules Michelet, Histoire de la Révolution française. Cited in Annie Crépin, 'Le Mythe de Valmy,' in Révolution et République: L'Exception Française, ed. Michel Vovelle (Paris: Editions Kimé, 1994), p. 470.

3 Michael Marrinan, Painting Politics for Louis-Philippe: Art and Ideology in Orléanist France, 1830-1848 (New Haven and London: Yale UP, 1988), pp. 117-18.

4 Annie Crépin, 'Le Mythe de Valmy,' p. 475.

5 Ian Germani, 'Reports from the Front: the Representation of Military Events in the Parisian Press, 1792-1793,' The Consortium on Revolutionary Europe, 1750-1850.

Selected Papers, 1994, pp. 44-57.

6 Annie Crépin, 'Le Mythe de Valmy,' pp. 468-72.

7 Hew Strachan, 'The Nation in Arms,' p. 54.

8 Ernest Picard, Au Service de la Nation: Lettres de Volontaires (1792-1798) (Paris: Librairie Félix Alcan, 1914), p. 127. 
9 Cited in Frank Attar, La Révolution Française Déclare la Guerre à l'Europe (Paris: Editions Complexe, 1992), pp. 181-82.

10 L'Ami du Roi (de Montjoye), le 4 mai, 1792.

11 Ibid., le 6 mai, 1792.

12 L'Ami du Peuple, le 6 mai, 1792.

13 Révolutions de Paris, du 28 avril au 5 mai, 1792.

14 Chronique de Paris, le 3 mai, 1792.

15 Annales Patriotiques et Littéraires de la France, le 5 mai, 1792.

16 Ibid., le 8 mai, 1792.

17 Chronique de Paris, le 5 mai, 1792.

18 Ibid., le 2 mai, 1792.

19 Postillon de la Guerre, le 8 mai, 1792.

20 Archives Parlementaires, vol. XLIII, pp. 249 \& 311.

21 Gazette universelle, le 22 mai, 1792.

22 Courrier des départemens, le 16 mai, 1792; Annales Patriotiques et Littéraires de la France, le 15 mai, 1792.

23 Courrier des départemens, le 15 mai, 1792.

24 Chronique de Paris, le 4 juin, 1792.

25 Courrier des départemens, le 6 juin, 1792.

26 Chronique de Paris, le 4 mai, 1792; Annales Patriotiques et Littéraires de la France, le 7 mai, 1792.

27 Chronique de Paris, le 8 juin, 1792.

28 Annales Patriotiques et Littéraires de la France, le 15 mai, 1792.

29 Alain Richard, Un Journal d'Armée sous la Révolution. Unpublished doctoral dissertation (Lille: Université de Lille III, 1978), pp. 124-25.

30 Courrier des départemens, le 17 juillet, 1792.

31 Courrier des départemens, le 22 juillet, 1792; Annales Patriotiques et Littéraires de la France, le 22 juillet, 1792.

32 Ibid., le 4 octobre, 1792. The deputies called for the Convention to compensate the Fernigs for the destruction of their home by the Austrians. A bequest was granted but subsequently rescinded when the sisters followed Dumouriez into exile. On the Fernigs, see also Joseph Bertal, Les Demoiselles de Fernig (Paris: Ch. Delagrave, 1893).

33 Courrier de Strasbourg, le 1 novembre, 1792.

34 Révolutions de Paris, du 25 août au 1 septembre, 1792.

35 Courrier des départemens, le 27 août, 1792.

36 Révolutions de Paris, du 1 au 8 septembre, 1792.

37 Annales Patriotiques et Littéraires de la France, le 7 septembre, 1792.

38 Révolutions de Paris, du 13 au 20 octobre, 1792.

39 Patriote français, le 29 septembre, 1792. 
40 Archives Parlementaires, vol. XL, p. 185.

41 Courrier des départemens, le 8 septembre, 1792.

42 Archives Parlementaires, vol. XLIX, p. 591.

43 E. Pionnier, Essai sur l'histoire de la Révolution à Verdun: 1789-1795 (Nancy: A. Crépin-Leblond, 1905); Xavier de Pétigny, Beaurepaire et le Premier Bataillon des Volontaires de Maine-et-Loire à Verdun, Juin-Septembre, 1792 (Angers: G. Grassin, 1911).

44 Courrier des départemens, le 9 décembre, 1792.

45 Dumouriez, Lettre du Général Dumouriez au Président de la Convention Nationale..., Du quartier-général de Mons, le 7 novembre 1792 (Paris: Imprimerie nationale, s.d.).

46 Ronsin, Détail Circonstancié de la Fameuse Bataille de Jémappe et de la Prise de Mons (n.p., n.d.).

47 Ami du Peuple, le 12 novembre, 1792.

48 Arthur Chuquet, L'Expédition de Custine (Paris: Librairie Léopold Cerf, 1892), p. 163.

49 Courrier des départemens, le 30 décembre, 1792.

50 Feuille du matin, le 26 décembre, 1792.

51 Courrier des départemens, le 11 et le 12 décembre, 1792.

52 Annales Patriotiques et Littéraires de la France, le 24 octobre, 1792. 


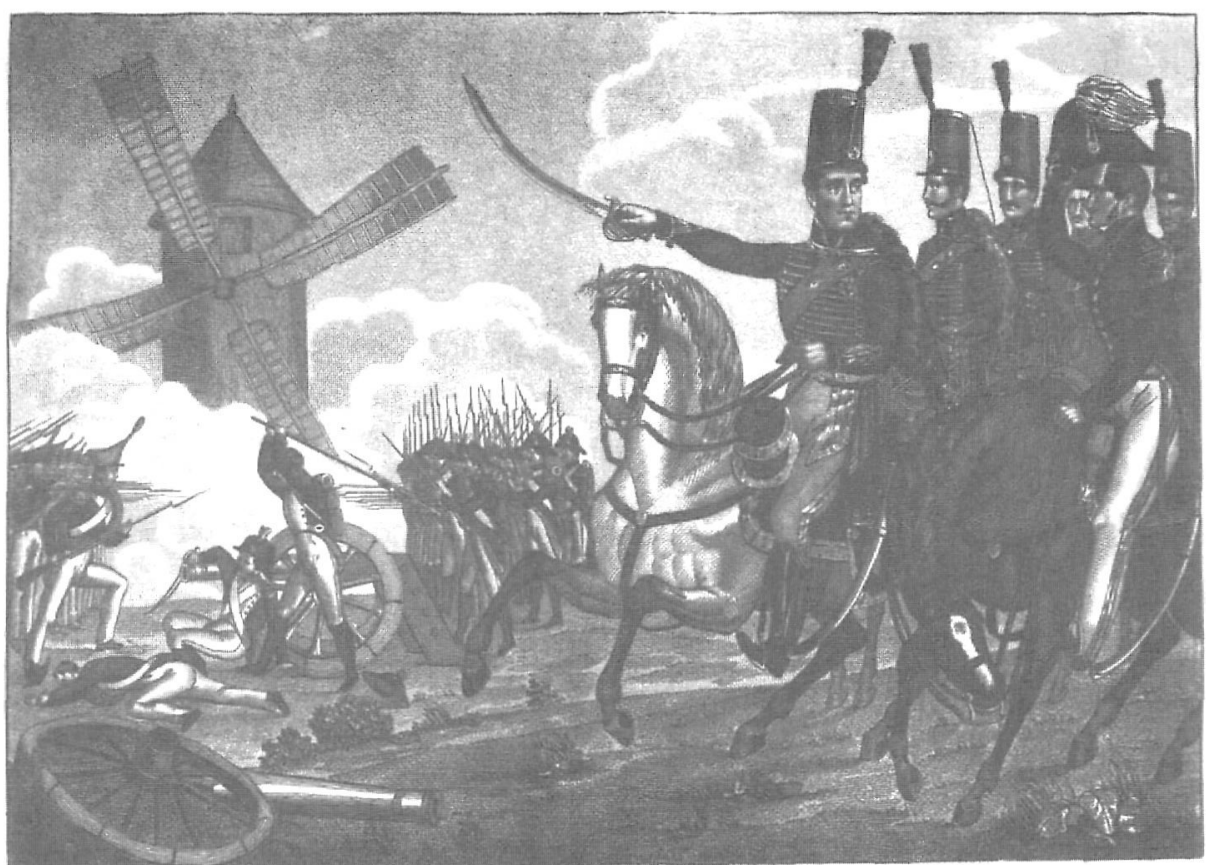

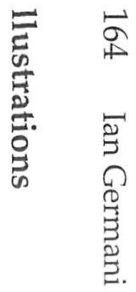

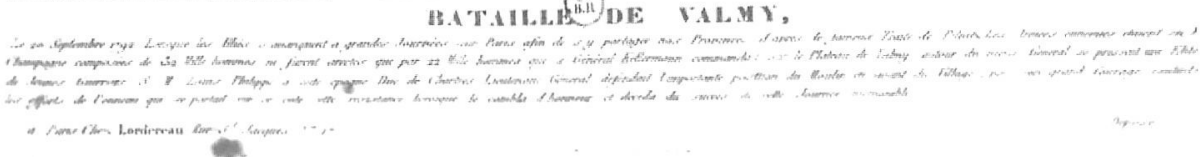

Illustration 1 Bibl. Nat Bataille de Valmy. 


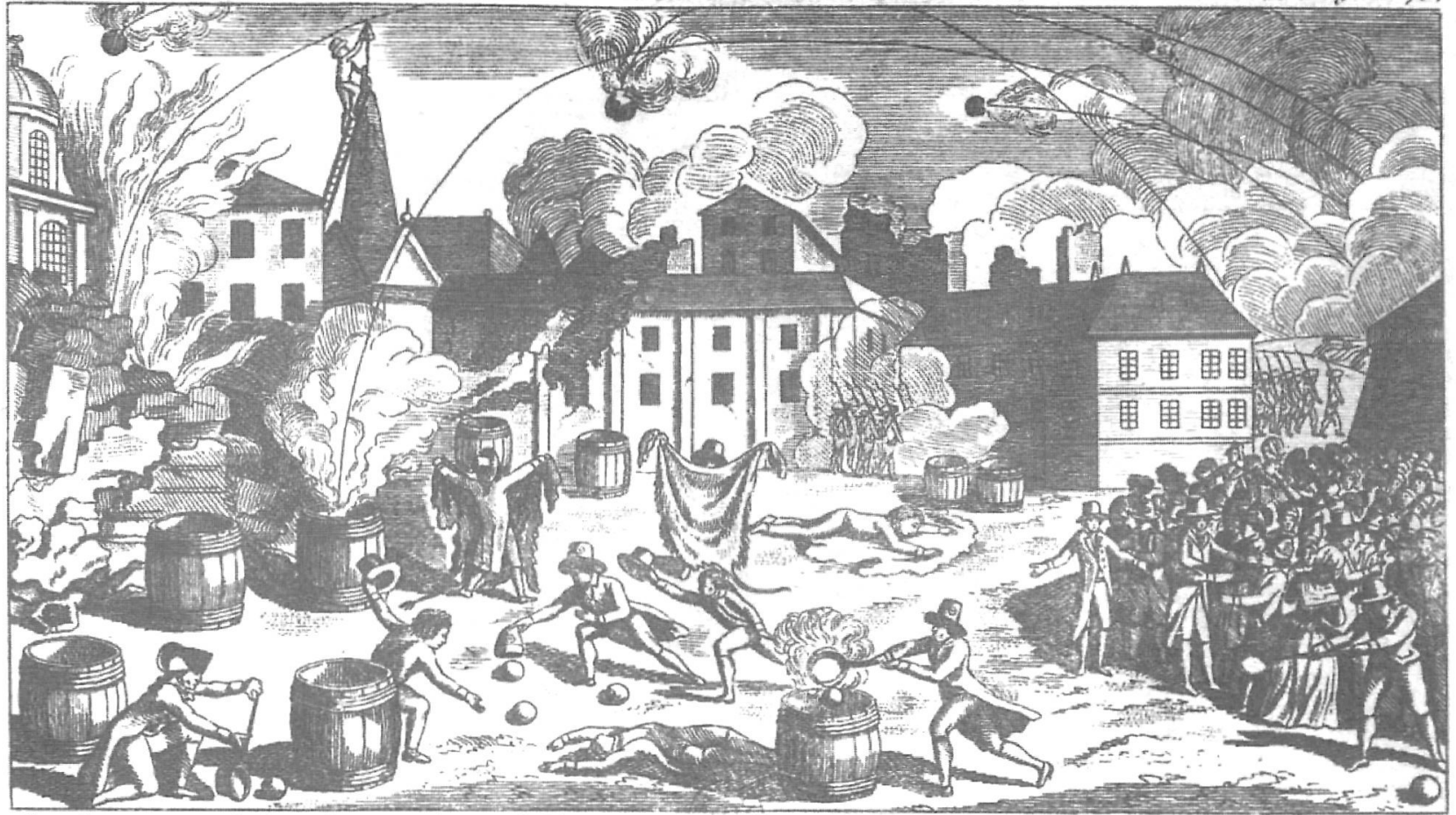




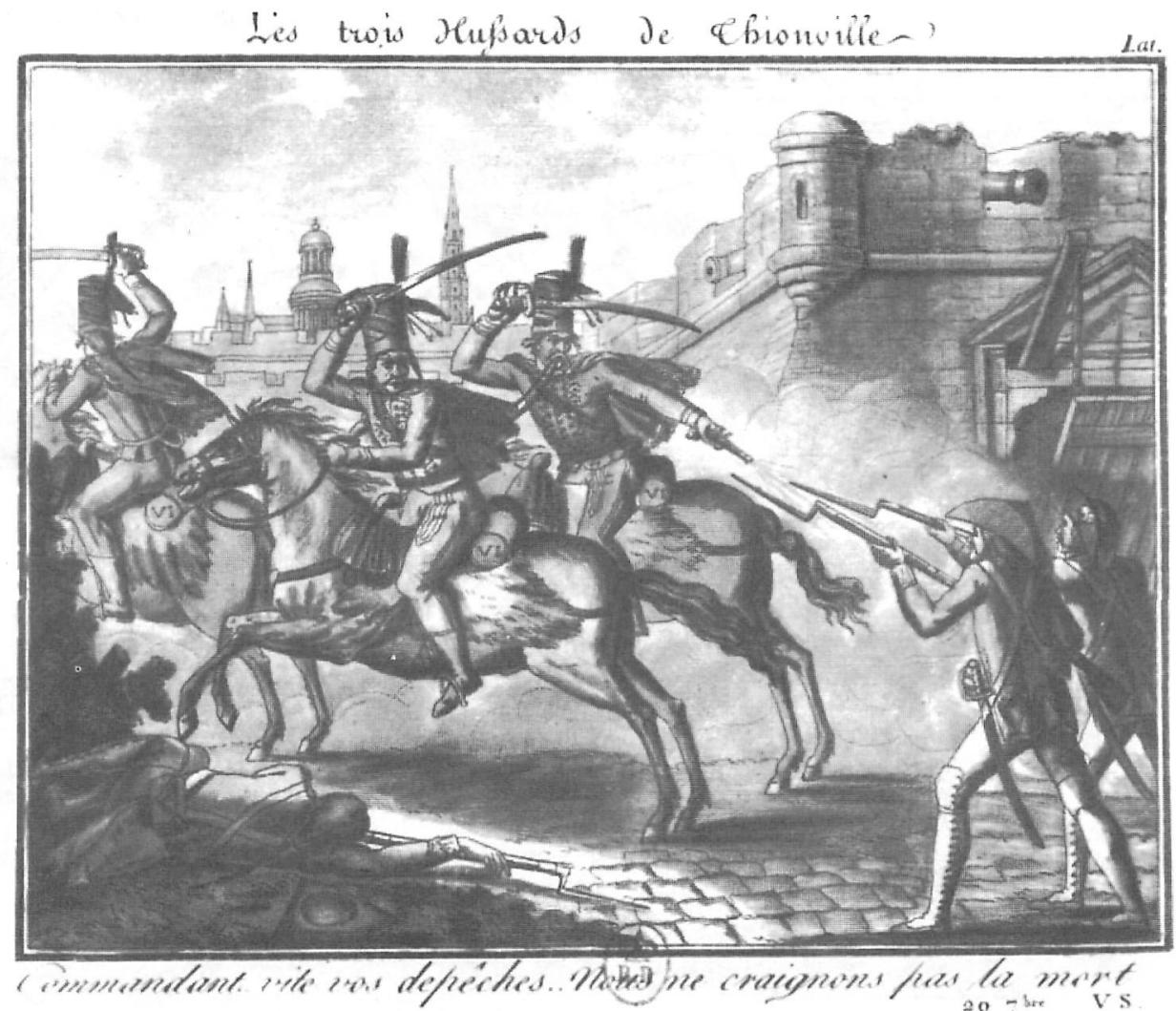




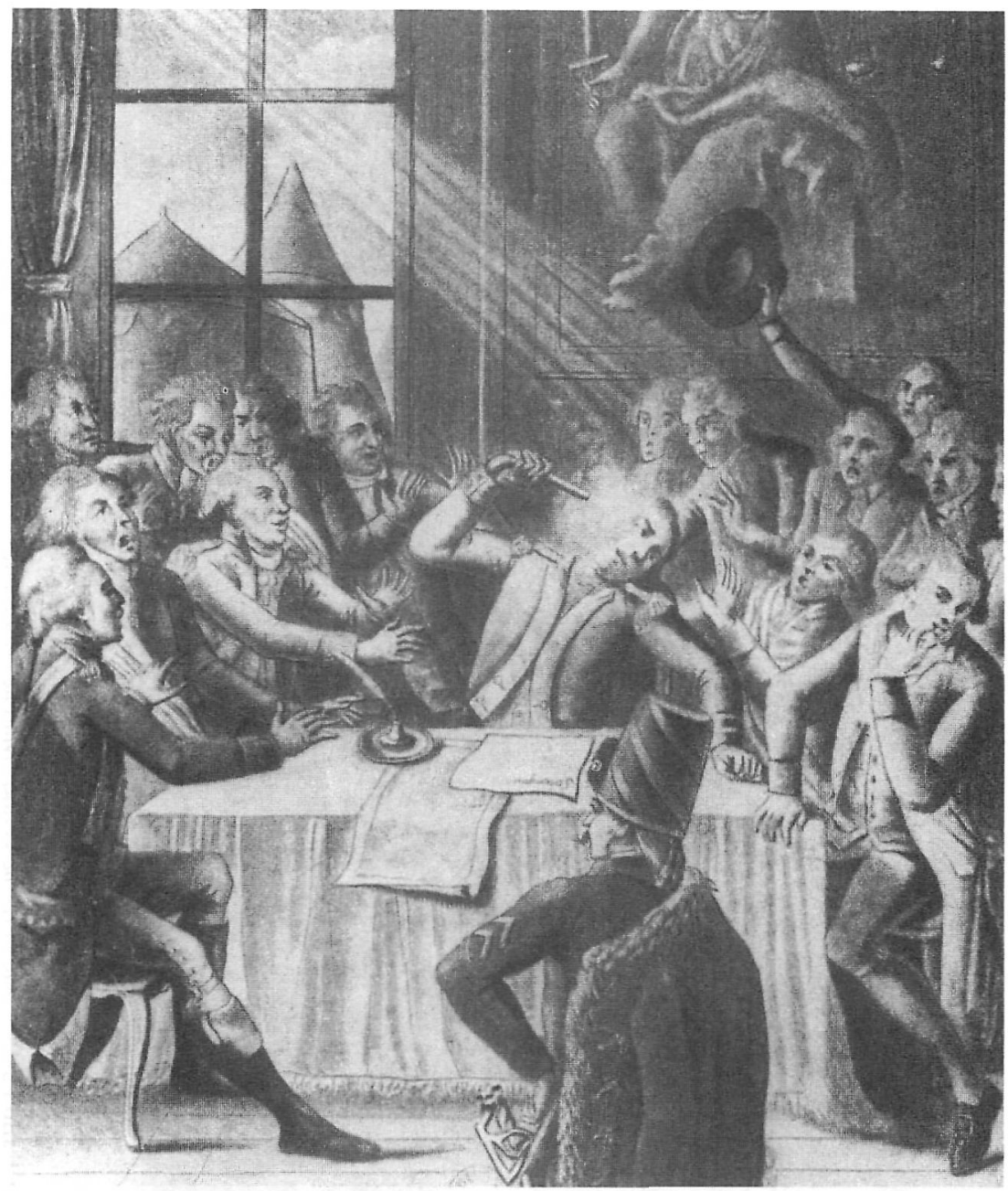

Illustration 4 Bibl. Nat Mort de Beaurepaire. 


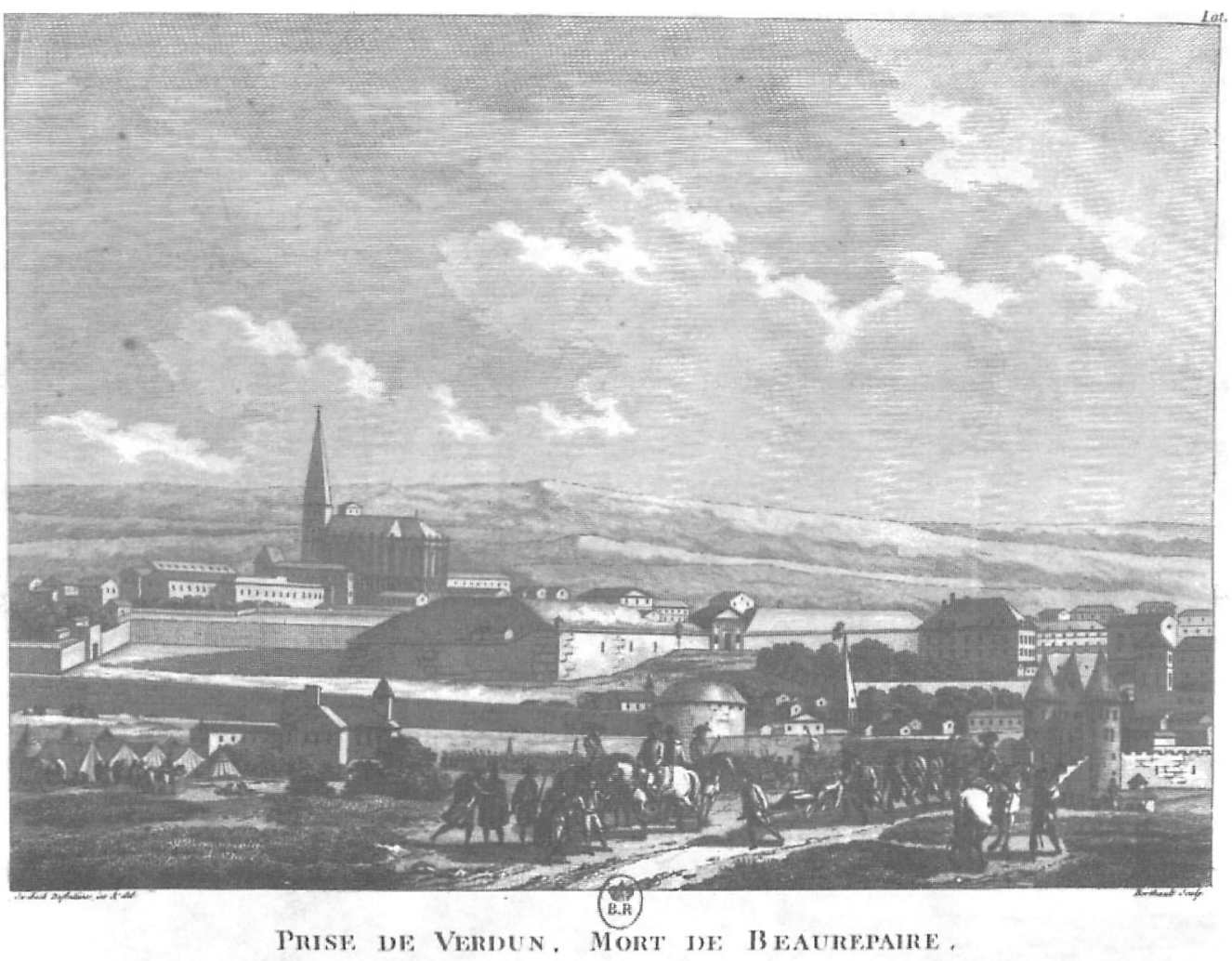

Illustration 5 Bibl. Nat. Prise de Verdun. Mort de Beaurepaire. 


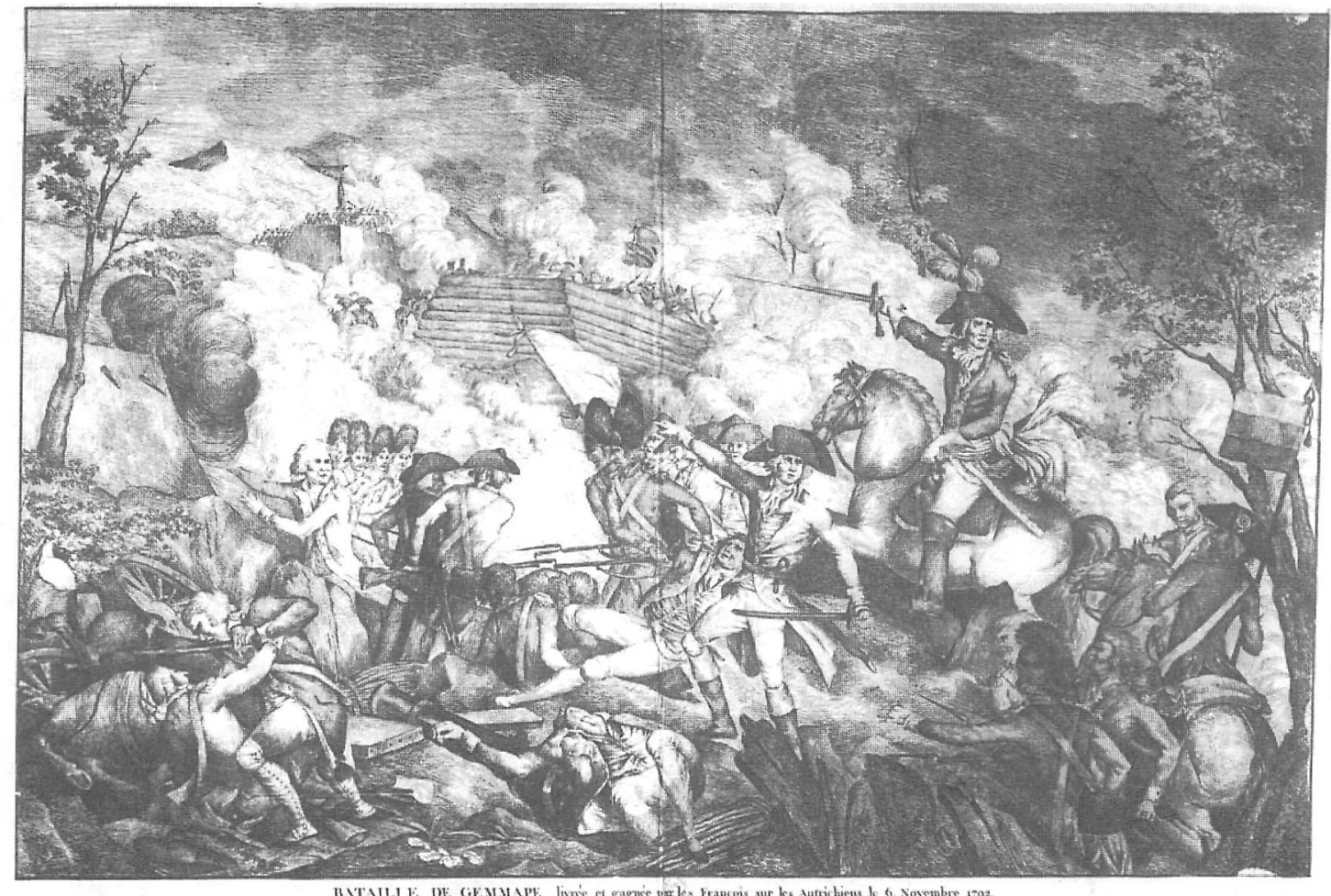

2
4

Illustration 6 Bibl. Nat. Bataille de Gemmape. 


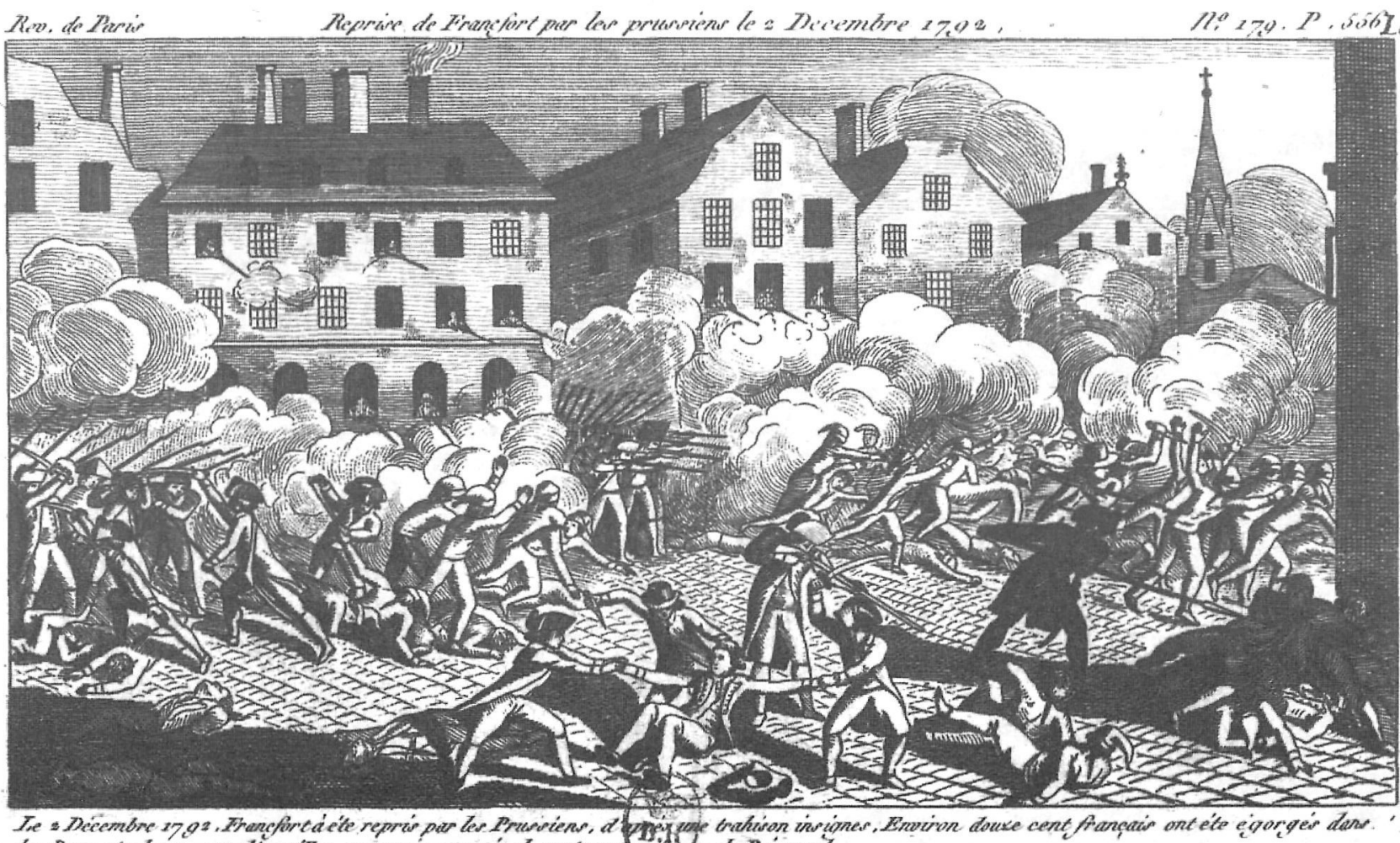

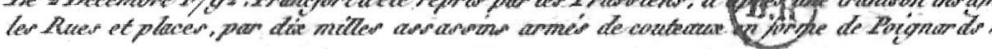

Illustration 7 Bibl. Nat. Reprise de Francfort par les Prussiens le 2 Décembre 1792. 